\title{
Physicochemical and mechanical properties of natural cellulosic fiber from Coccinia Indica and its epoxy composites
}

\author{
M. Bhuvaneshwaran ${ }^{1), *)}$, P.S. Sampath ${ }^{2)}$, S. Balu ${ }^{3)}$, S. Sagadevan ${ }^{4)}$ \\ DOI: dx.doi.org/10.14314/polimery.2019.10.2
}

\begin{abstract}
This paper reports on the physicochemical, and mechanical characterization of Coccinia Indica (CI) fiber. The Coccinia Indica fiber (CIF) reinforced epoxy composite is fabricated using a compression molding process. The results of the chemical analysis of CIF showed that the fiber contained more cellulose and skimpy lignin, ash, and wax content. Scanning electron microscopy (SEM) analysis revealed that the fiber possessed a multicellular structure. The Fourier transform infrared spectroscopy (FT-IR) and X-ray diffraction (XRD) studies revealed that CIF shows a crystallinity index of 30\%. The thermogravimetric analysis (TGA) indicated that the major degradation of fibers occurred in the temperature range of $204.2{ }^{\circ} \mathrm{C}$ to $376.3^{\circ} \mathrm{C}$. The various mechanical test results showed that the tensile, flexural and impact strength increased with increase in fiber length and weight percentage. The maximum properties were found at $30 \mathrm{~mm}$ fiber length and 35\% of fiber loading. The SEM fractography result showed that the predominant mechanism for mechanical failure was due to fiber pull out, matrix fracture and fiber fracture.
\end{abstract}

Keywords: Coccinia Indica fiber, natural fiber composite, fiber loading, fiber length.

\section{Właściwości fizykochemiczne i mechaniczne naturalnych celulozowych włókien Coccinia Indica i ich kompozytów na osnowie żywicy epoksydowej}

Streszczenie: Oceniono fizykochemiczne i mechaniczne właściwości celulozowych włókien Coccinia Indica (CIF). Kompozyty na osnowie żywicy epoksydowej wzmocnionej CIF wytwarzano w procesie wytłaczania. Na podstawie analizy chemicznej stwierdzono, że włókna CIF zawierają dużą część celulozy i niewielką ligniny, popiołu i wosku. Metodą skaningowej mikroskopii elektronowej (SEM) wykazano, że włókna CI mają strukturę wielokomórkową. Na podstawie wyników spektroskopii w podczerwieni z transformacją Fouriera (FT-IR) i dyfrakcji rentgenowskiej (XRD) stwierdzono, że stopień krystaliczności CIF wynosi $30 \%$. Analiza termograwimetryczna (TGA) wykazała, że główna degradacja włókien zachodzi w temperaturze z zakresu $204,2-376,3^{\circ} \mathrm{C}$. Wyniki testów mechanicznych dowodzą, że wartości wytrzymałości na rozciąganie, zginanie i uderzenie zwiększały się wraz z długością włókien i ich zawartością w kompozycie. Maksymalnymi wartościami właściwości odznaczał się kompozyt na bazie żywicy epoksydowej napełnionej 35\% mas. włókien Coccinia Indica o długości $30 \mathrm{~mm}$. Wyniki analizy SEM wykazały, że decydujący wpływ na uszkodzenie mechaniczne miało wyciąganie włókien, pękanie osnowy i pękanie włókien.

Słowa kluczowe: włókna Coccinia Indica, kompozyty z naturalnymi włóknami, zawartość włókien, długość wlókien.

In the recent decades, the utilization of biodegradable materials such as natural fibers in the composite fabrication is fascinating to the researchers because they are more innocuous for the environment, recyclable, cheap and do not pose of health risks. Natural fiber reinforced composites (NFRC) have been assessed for various me- chanical properties and have been found to be a substitute for the synthetic fiber reinforced composites (SFRC). The various mechanical properties of NFRC and SFRC were compared by Harish et al. [1]. They reported that even though the synthetic composites are better than the NFRC, the disposal of SFRC is problematic owing to the

\footnotetext{
1) K.S.R College of Engineering, Department of Mechanical Engineering, Tiruchengode, Tamilnadu, India.

2) KS Rangasamy College of Technology, Department of Mechanical Engineering, Tiruchengode, Tamilnadu, India.

3) PSNA College of Engineering and Technology, Department of Mechanical Engineering, Dindigul, Tamilnadu, India.

4) University of Malaya, Nanotechnology \& Catalysis Research Centre, Kuala Lumpur 50603, Malaysia.

*) Author for correspondence; email: bhuvansparks2017@gmail.com
} 
environmental hazards. Bodros [2] investigated the Urtica Dioica natural fiber and reported that the natural fiber could be used to fabricate eco-friendly NFRC. He found that the biocomposites might be produced using natural fibers with a biopolymer matrix. Boopathi [3] characterized one of the natural fibers named borassus fruit fiber and reported that its higher cellulose content offered greater strength to the natural fiber and its lower density enabled the fiber to fabricate lightweight composite materials. He compared the mechanical property of natural fibers like jowar, sisal, and bamboo with polyester matrix and affirmed that the composite produced with jowar fibers showed better strength than the sisal and bamboo fiber composites. Moreover, the author assimilated that the jowar fiber could be used to manufacture lightweight composites due to its low density [4]. Holbery [5] has reported that the epoxy resin is widely used matrix material to fabricate natural fiber composite and those composites are extensively used in the automobile industries. The author has further stated that the epoxy resin offers high performance and immunity to environmental degradation. Fabricated household telephone stand using a natural composite composed of banana fiber and epoxy resin has been found to be eco-friendly and the composite is used for making low-cost household appliances [6]. The mechanical and thermal properties of Schumannianthus Dichotomous (Murta) natural fiber reinforced epoxy resin composite have been studied and it has been found that the optimum length and weight percentage of fiber loading are important in order to attain the desired properties [7]. Sreenivasan et al. reported that the properties of the composite strongly depend on the fiber length, further, they found that $30 \mathrm{~mm}$ fiber length is the critical length $\left(l_{c}\right)$ of the fiber [8]. Matthews et al. stated that the $l_{c}$ of the fiber varied based on a particular matrix/fiber system [9]. It is inferred from the literature that the natural fiber composites play a vital role in the present era and the low-density natural fibers are being used to manufacture lightweight composites.

In this investigation, the low-density natural fiber of Coccinia Indica and epoxy resin have been used to fabricate the composite. Thermo-physical-mechanical proper- ties and morphology characterizations have been carried out on the Coccinia Indica fiber. To determine the influence of fiber loading on the mechanical and morphology properties of the composite, it has been fabricated with different weights of natural fiber such as $25 \%, 30 \%, 35 \%$ and $40 \%$ CIF.

\section{EXPERIMENTAL PART}

\section{Materials}

The matured Coccinia Indica (CI) plants were collected from Kanuvukarai Village, Coimbatore district, Tamil Nadu, India, which is a medicinal plant [10-12] under the family of Cucurbitaceae. Figure 1 shows the Coccinia Indica stems and extracted fibers after the microbial degradation process. In this process first, the fibers were separated from the Coccinia Indica plant stem and they were dipped into the water for 3 weeks. Then the soaked stems were cleaned and dried in the open atmosphere. Finally, the fibers were extracted from the dried stems by combing with the brush and the physical properties were determined as per the standards [3]. The epoxy trade grade of LY 556 was used as a matrix material which had a density of 1.05 to $1.20 \mathrm{~g} / \mathrm{cm}^{3}$ and the hardener trade grade of HY951 having a density of 0.98 to $0.99 \mathrm{~g} / \mathrm{cm}^{3}$, were purchased from the Covai Seenu \& Company, Coimbatore, South India.

\section{Composite fabrication}

The composites were fabricated using a compression molding process. The mold size of $300 \mathrm{~mm} \times 300 \mathrm{~mm}$ $\times 3 \mathrm{~mm}$ was used to manufacture the composites. The internal surface of the mold was coated with wax polish for removing the polymer composites from the mold. Epoxy and hardener mixed at the ratio of $10: 1$. The CIFs were hewed into various lengths such as 10, 20, 30, and $40 \mathrm{~mm}$. Up to $10 \mathrm{MPa}$ compressive force was applied during the curing process for 24 hours. To enable the ease of identification and discussion, the samples were named U1025, U1030, U1035, and U1040 up to U4040 according to their

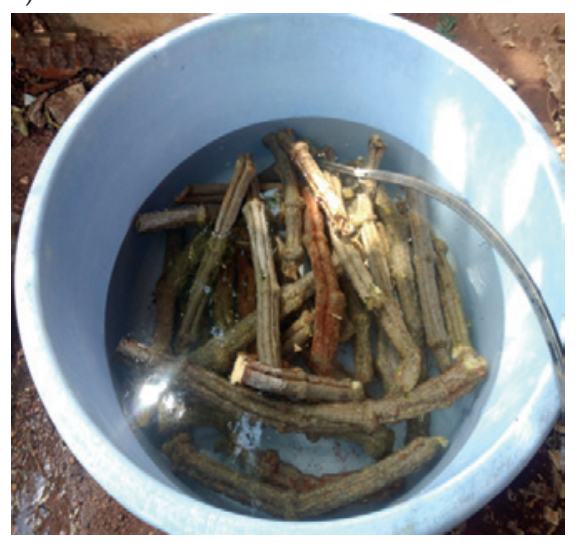

b)

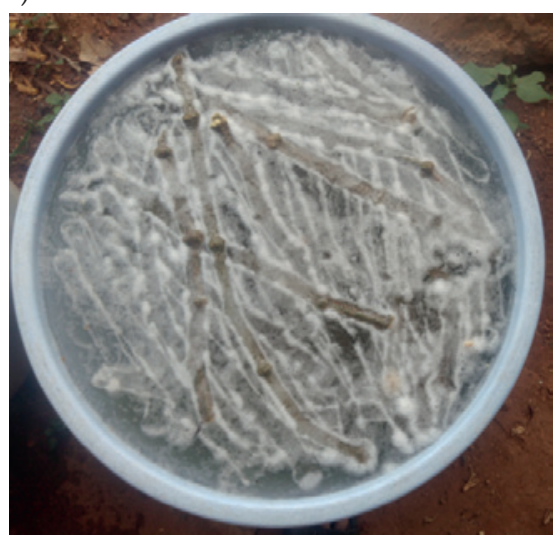

c)

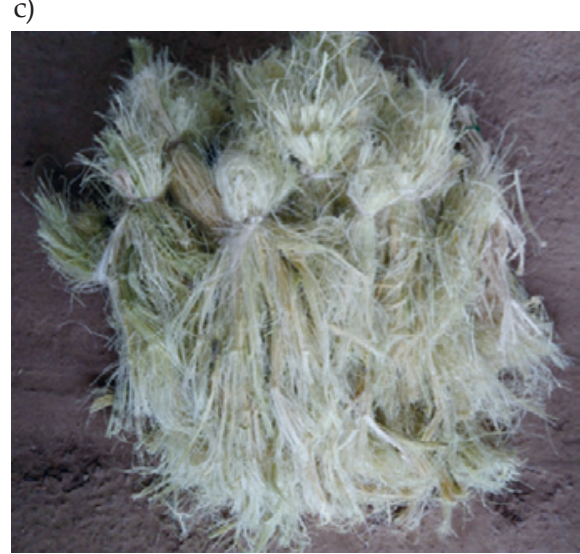

Fig. 1. Fiber extraction: a) CI sliced and immersed in water, b) immersed CI after 3 weeks, c) extracted CI fibers 
a)

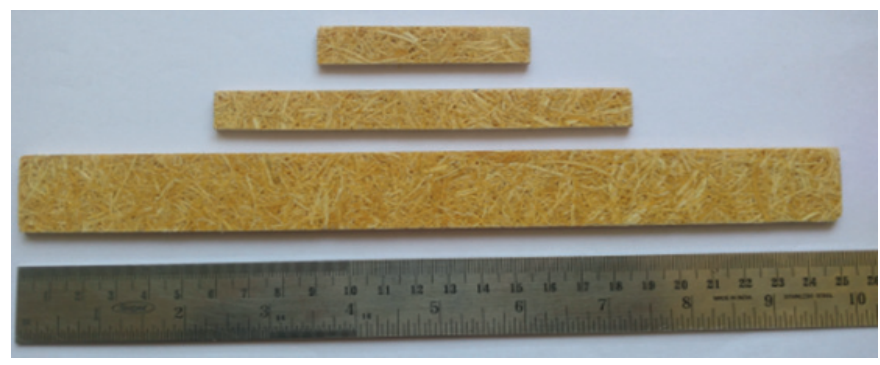

Fig. 2. Test specimens: a) before testing, b) after testing

length and the weight percentage of the fibers. Here $U$ denotes fiber in untreated condition, the first two Arabic numerals denote the length of the fiber and the last two numerals denote weight percentage of the fiber.

\section{Methods of testing}

- To compute the tensile strength of the single fiber, tensile tests were carried out on the extracted fiber as per ASTM D3822 M-14 standards. Instron-5500R tensile testing machine with the aid of $1 \mathrm{kN}$ load cell was employed in this study. During testing, $50 \mathrm{~mm}$ gauge length specimen was subjected to a crosshead speed of $5 \mathrm{~mm} / \mathrm{min}$ and the entire test was performed under room temperature.

- After fabrication, the composites were sliced into different samples as shown Fig. 2 for conducting various mechanical testing. ASTM D3039, ASTM D790, ASTM D256, and ASTM D3410 standards were used for the preparation of tensile, flexural, impact and compression test specimens, respectively. The Kalpak universal testing machine was used for tensile, compression and three-point flexural tests and the Karl Frank GMBH 53568 impact testing machine was used for determining the impact toughness. In order to ensure the test results, five samples were tested in each case and average results were computed.

- The chemical analysis of the single fiber was done to determine the content of cellulose, lignin, wax, ash, moisture, and density as per the standards [13-15].

- To figure out the functional groups in CIF, FT-IR analysis was carried out using Perkin Elmer RXI FT-IR tester with the scanning rate of 30 scans per minute.

- The CIF crystallinity index was calculated using powder XRD method with help of XPERT-PRO diffractometer. The parameters used in the XRD analysis were monochromatic $\mathrm{CuK} \alpha$ radiation with the wavelength of $0.154 \mathrm{~nm}$, current $30 \mathrm{~mA}$, copper anode and the signal absorption ranges between $10^{\circ}$ and $80^{\circ}$.

- Thermogravimetric analysis (TG) and difference thermogravimetric analysis (DTG) was performed on the CIF samples using Jupiter simultaneous thermal analyzer (Model STA, Netzsch). Nitrogen inert gas was used to avoid the oxidation of samples during tests. The sample was kept on the ceramic crucible to establish proper b)

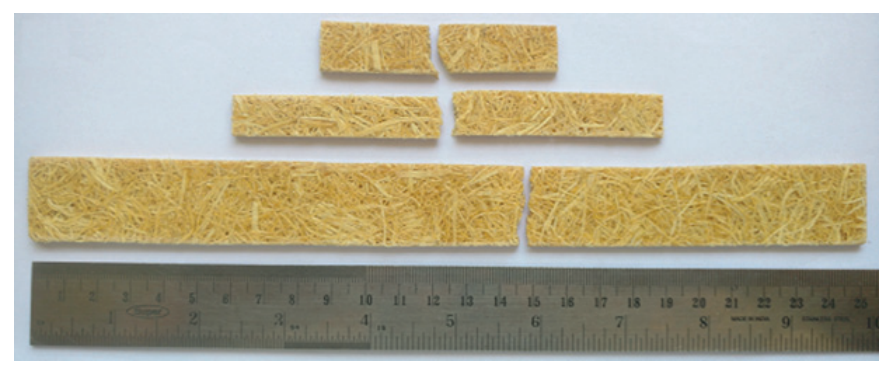

contact between the thermocouple and CIF samples. The heating rate of $10{ }^{\circ} \mathrm{C} / \mathrm{min}$ over a range of $30-1000{ }^{\circ} \mathrm{C}$ was utilized in this experiment.

- To reveal the surface morphology of the CIF, its composites and failure area in the mechanical test, SEM analysis was carried out. Before SEM analysis, gold sputtering was done on the sample's surfaces to avoid electrical charge accumulation.

\section{RESULTS AND DISCUSSION}

\section{Physicochemical properties of CIF}

The XRD results are depicted in Fig. 3 and a couple of well-defined peaks could be observed. The peak at $2 \theta=22.37^{\circ}(200)$ clearly indicates the cellulose content and the peak at $2 \theta=15.66^{\circ}(100)$ shows the typical non-cellulose materials which could be lignin, wax, etc.

Commonly, the crystallinity index is used to measure the crystallinity of cellulose with respect to the amorphous materials. The following expression was employed to compute the crystallinity index [16]:

$$
C r l=\frac{\left(I_{002}-I_{\mathrm{AM}}\right)}{I_{002}} \cdot 100 \%
$$

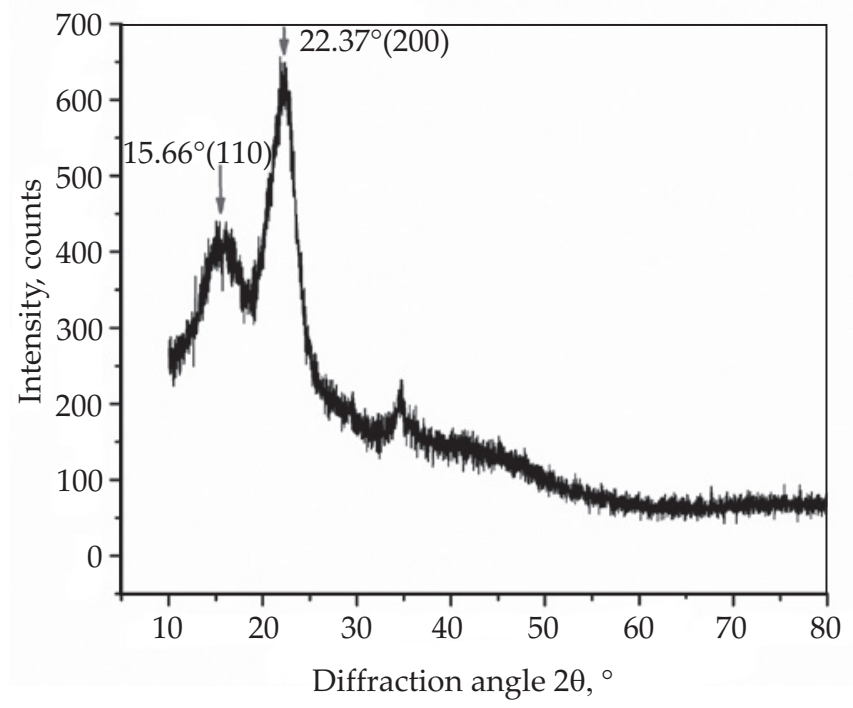

Fig. 3. XRD pattern of CIF 


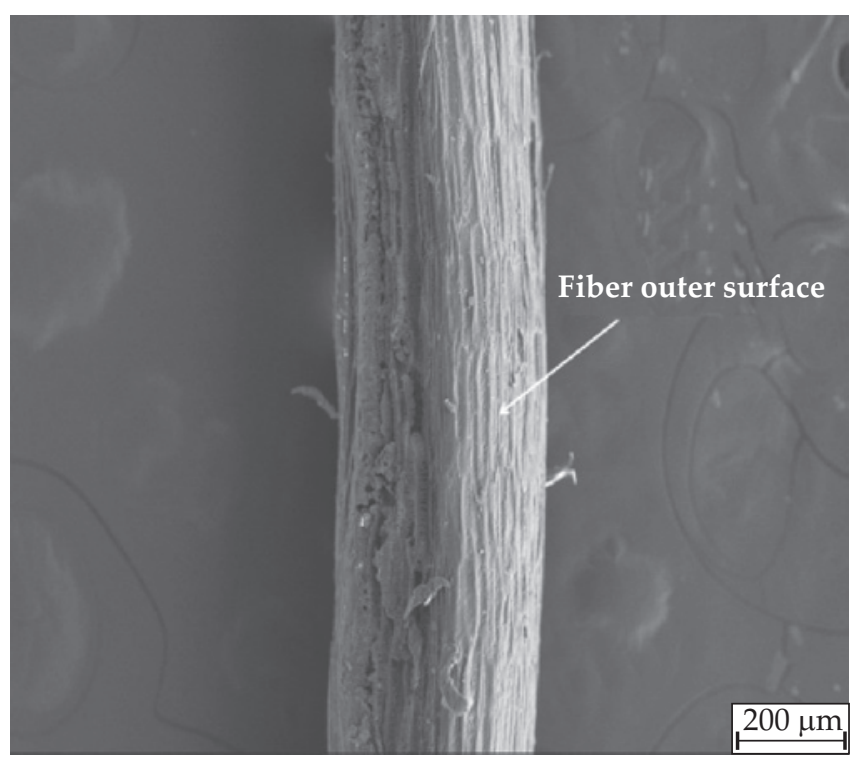

Fig. 4. SEM image of single CIF at a magnification 500×

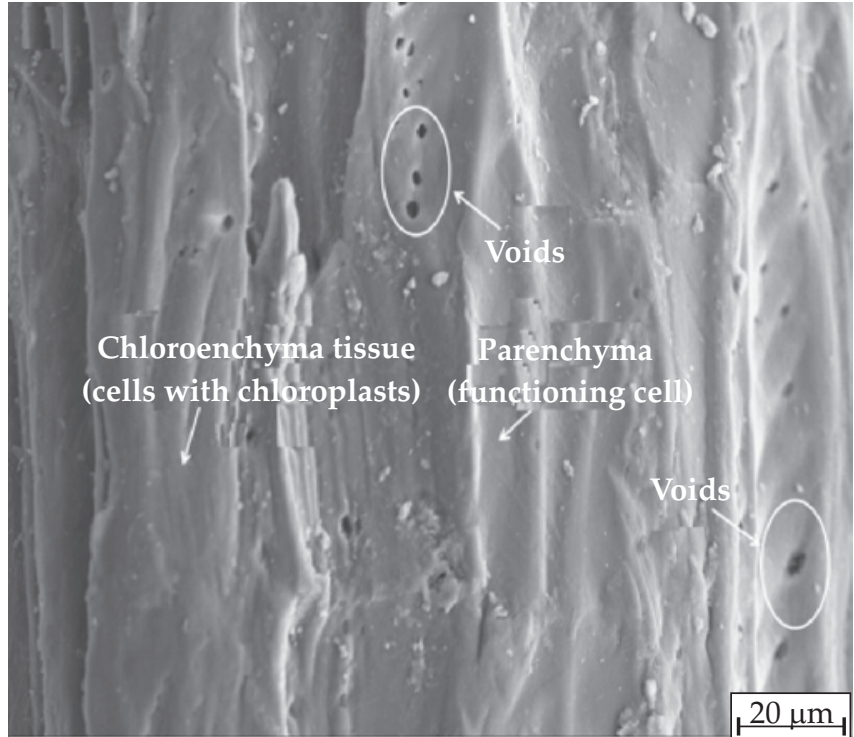

Fig. 5. SEM image of single CIF at a magnification $5000 \times$

T a b l e 1. Physicochemical properties of the CIF

\begin{tabular}{c|c|c|c|c|c|c|c|c}
\hline $\begin{array}{c}\text { Cellulose } \\
\%\end{array}$ & $\begin{array}{c}\text { Hemicellulose } \\
\%\end{array}$ & $\begin{array}{c}\text { Lignin } \\
\%\end{array}$ & $\begin{array}{c}\text { Wax } \\
\%\end{array}$ & $\begin{array}{c}\text { Ash } \\
\%\end{array}$ & $\begin{array}{c}\text { Moisture } \\
\%\end{array}$ & $\begin{array}{c}\text { Density } \\
\mathrm{kg} / \mathrm{m}^{3}\end{array}$ & $\begin{array}{c}\text { Elongation } \\
\%\end{array}$ & $\begin{array}{c}\text { Tensile strength } \\
\mathrm{MPa}\end{array}$ \\
\hline 69.6 & 14.1 & 18.8 & 0.25 & 1.39 & 9.7 & 1370 & 4.5 & 645 \\
\hline
\end{tabular}

where: $C r I$ - the relative degree of the crystallinity, $I_{002}$ - the maximum intensity, $I_{\mathrm{AM}}$ - the minimum intensity. The crystallinity index of the CIF was found to be $30 \%$. The crystallite size $(L)$ of CIF was determined by Scherer's equations [17]:

$$
L=\frac{k \lambda}{\beta \cos \theta}
$$

where: $k$ - Scherer's constant (0.94), $\beta$ - the peak's FWHM (field/full width at half maximum), $\lambda$ - the wavelength of the radiation.

The chemical analysis was performed on the CIF and the results are presented in Table 1 . Generally, the presence of cellulose and lignin content offers generous tensile property and rigidity to the fiber, respectively. Similarly, the wax, ash, and moisture content present in the fiber reduce the interfacial bonding between the fiber and the matrix material. In this study, the tested CIF contained high cellulose and lignin contents with low wax and ash contents. Figure 4 and Fig. 5 show the SEM photograph of single CIF. It is inferred from Fig. 4 that the CIF possesses a multi-cellular structure with a diameter of $15 \mu \mathrm{m}$ (approximately). Further, it is observed that the CIF is soft in nature and looks cylindrical. The cylindrical morphology in the natural fiber increases the specific area and thus favors the chemical processes. Similarly, it is observed from Fig. 5 that the functional groups of parenchyma and chlorenchyma tissues are present in the cell wall of the CIF plant stem which offers better adhesion and mechanical properties to the composite.

$\mathrm{T}$ a b 1 e 2. FT-IR wave numbers and transmittance peaks of CIF

\begin{tabular}{c|c|c|c}
\hline Bond/vibration & CIF peak, $\mathrm{cm}^{-1}$ & Assigned functional groups & Reference \\
\hline O-H/stretching & 3356 & Hydrogen bonded hydroxyl groups of cellulose & Indran $e t$ al. [18] \\
C-H/stretching & 2924 & Methylene unit of cellulose & Kiruthika et al. [19] \\
C=O/stretching & 1735 & Carbonyl group of hemicellulose & Porras $e t$ al. [20] \\
C=O/stretching & 1654 & Carbonyl group of lignin, water & Porras $e t$ al. [20] \\
OH/bending & 1236 & -COO groups of cellulose and hemicellulose & Belouadah $e t$ al. [21] \\
C-O/stretching & 1031 & C-O-C pyranose ring of cellulose & Reddy et al. [22] \\
C-O-C/skeletal & 897 & $\beta$-glucosidic linkages of cellulose & Reddy et al. [22] \\
C-OH & & &
\end{tabular}




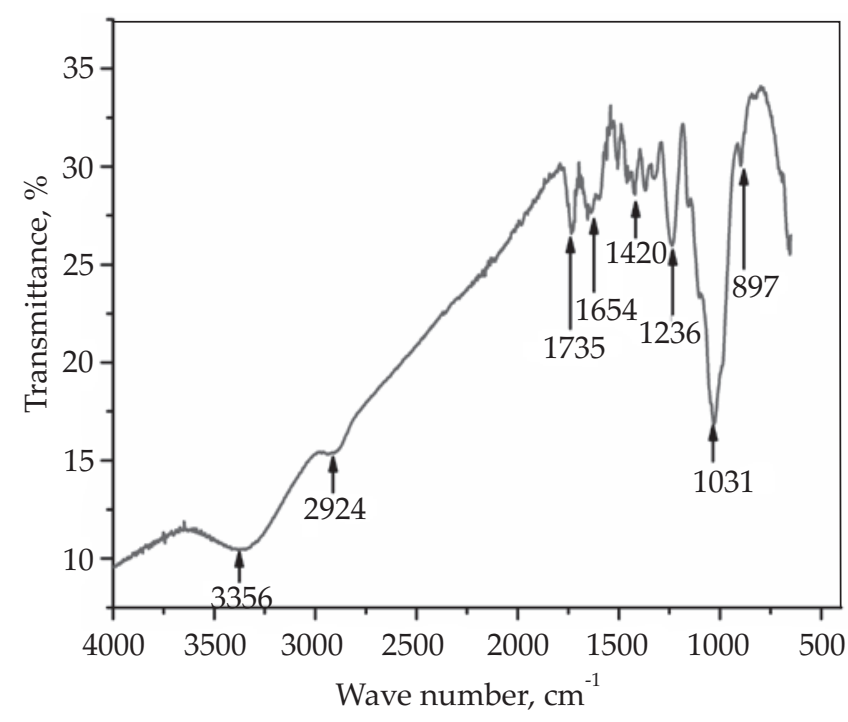

Fig. 6. FT-IR spectrum of CIF

To determine the functional groups present in the CIF, the FT-IR analysis was conducted on the prepared samples and the results are presented in Fig. 6 and Table 2 [18-22]. Thermal characteristics of the CIF were studied using TG and DTG curves obtained from the thermogravimetry analysis as shown in Fig. 7. It is inferred from the figure that the degradation of CIF has occurred in different stages. In the first stage (up to $69.2^{\circ} \mathrm{C}$ ) evaporation of moisture content which is present in the CIF takes place and the mass change has been found to be $9.1 \%$ as predicted by Moran et al. [23]. During the second stage, the degradation was noticed in the temperature range from $69.2{ }^{\circ} \mathrm{C}$ to $204.2^{\circ} \mathrm{C}$ with the mass change of $19.3 \%$ as a result of depolymerization of hemicelluloses as reported by Hee-Soo Kim and French [24, 25]. The third stage (between $204.2^{\circ} \mathrm{C}$ and $376.3^{\circ} \mathrm{C}$ ) involves the degradation of cellulose and part of lignin with the mass change of $51.0 \%[26,27]$.

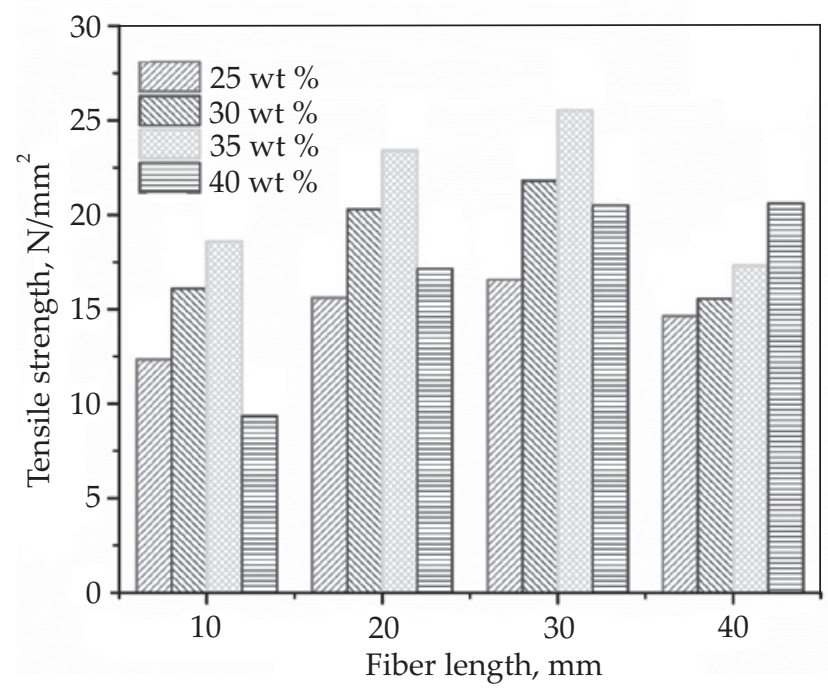

Fig. 8. Tensile strength of CIF composites

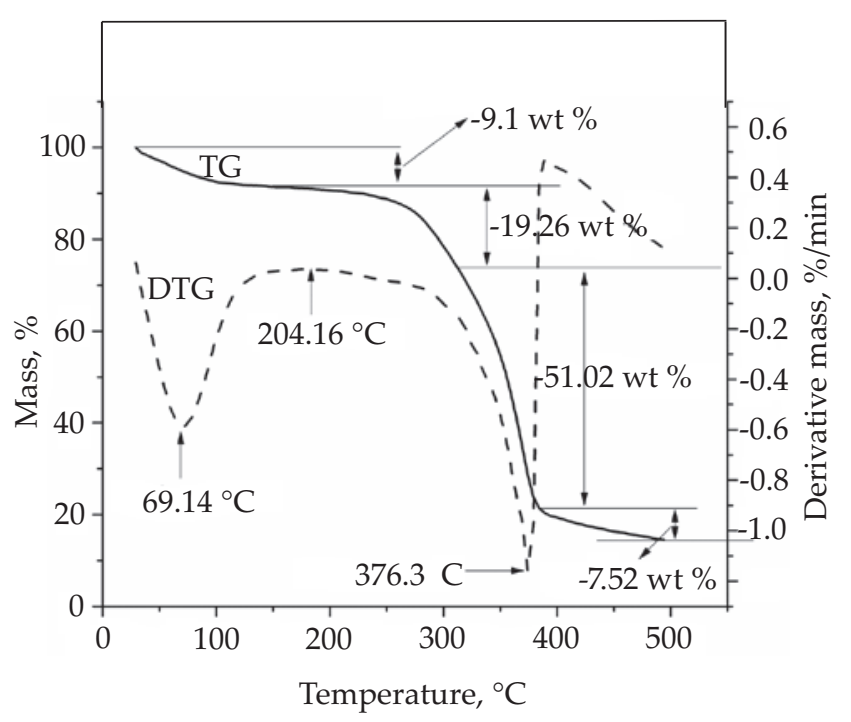

Fig. 7. TG/DTG curves of CIF

In the final stage, the temperature ranges above $376.3^{\circ} \mathrm{C}$, the degradation of part of cellulose and lignin, including the breaking of aromatic structure and the mass change was observed to be $7.5 \%$ [28].

\section{Mechanical properties of CIF/epoxy resin composites}

\section{Tensile studies}

The tensile studies were carried out on the CIF composite according to ASTM standards. In this investigation, it is inferred from Fig. 8 and Table 3 that the tensile strength increases with increase in the fiber length up to $30 \mathrm{~mm}$ after that it decreases, thereby indicating that $l_{\mathrm{c}}$ for this CIF composite is $30 \mathrm{~mm}$. The result obtained in this study matches the result reported by Joseph [29]. Similarly, it is found that the tensile strength increases with an increase in the fiber weight percentage up to $35 \%$ and then

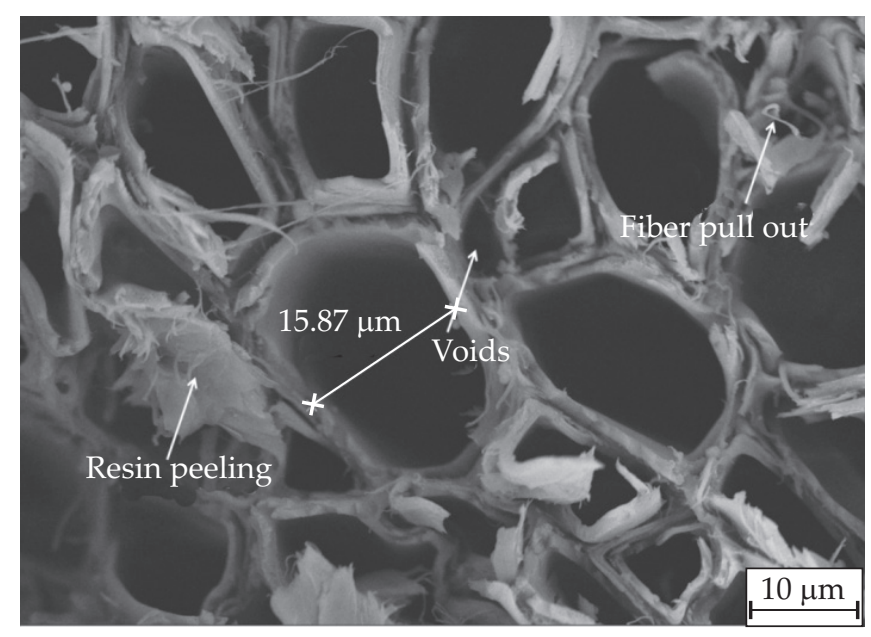

Fig. 9. SEM image of tensile sample of U3035 at a magnification $10000 x$ 
$\mathrm{T}$ a b l e 3. Mechanical properties of Coccinia Indica fiber reinforced composites

\begin{tabular}{|c|c|c|c|c|}
\hline Sample name & $\begin{array}{l}\text { Tensile strength } \\
\mathrm{N} / \mathrm{mm}^{2}\end{array}$ & $\begin{array}{c}\text { Flexural strength } \\
\mathrm{MPa}\end{array}$ & $\begin{array}{l}\text { Impact strength } \\
\mathrm{J} / \mathrm{m}\end{array}$ & $\begin{array}{c}\text { Compressive strength } \\
\mathrm{MPa}\end{array}$ \\
\hline U1025 & 12.34 & 31.15 & 183 & 23.6 \\
\hline U1030 & 16.11 & 38.18 & 217 & 27.1 \\
\hline U1035 & 18.59 & 53.66 & 266 & 36.9 \\
\hline U1040 & 15.33 & 45.81 & 183 & 31.3 \\
\hline U2025 & 15.61 & 35.50 & 217 & 25.4 \\
\hline U2030 & 20.29 & 45.04 & 233 & 31.0 \\
\hline U2035 & 23.41 & 61.68 & 283 & 36.0 \\
\hline U2040 & 17.15 & 44.62 & 266 & 32.7 \\
\hline U3025 & 16.57 & 45.76 & 317 & 25.8 \\
\hline U3030 & 21.80 & 60.84 & 350 & 28.5 \\
\hline U3035 & 25.54 & 66.45 & 383 & 34.4 \\
\hline U3040 & 20.51 & 52.41 & 200 & 31.1 \\
\hline U4025 & 14.65 & 37.03 & 183 & 21.3 \\
\hline U4030 & 15.57 & 55.69 & 250 & 25.5 \\
\hline U4035 & 17.33 & 58.19 & 300 & 34.1 \\
\hline U4040 & 15.62 & 47.25 & 230 & 31.1 \\
\hline
\end{tabular}

it decreases because of little load transmission from the fiber to the matrix. This result indicates that the optimum fiber weight percentage is $35 \%$ for this particular matrix and fiber system. Figure 9 depicts the SEM fractography of the tensile fracture surface of U3035 sample. It is inferred from the figure that the major fracture mechanism is fiber pull out and it is evident, as the voids in fracture surface are observed. The reason for the fiber pull out is

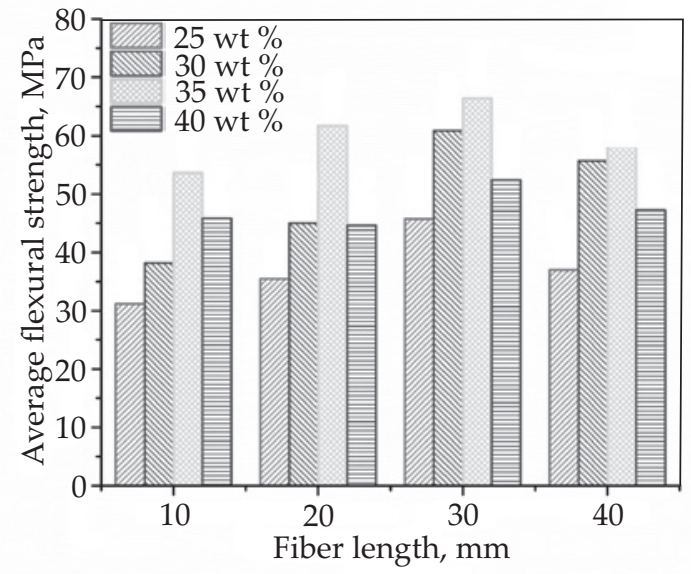

Fig. 10. Flexural strength of CIF composites caused by tensile loading [8]. The sample named as U3035 shows a higher tensile strength of $25.5 \mathrm{~N} / \mathrm{mm}^{2}$ when compared with the other combinations of the Coccinia Indica fiber reinforced epoxy composite.

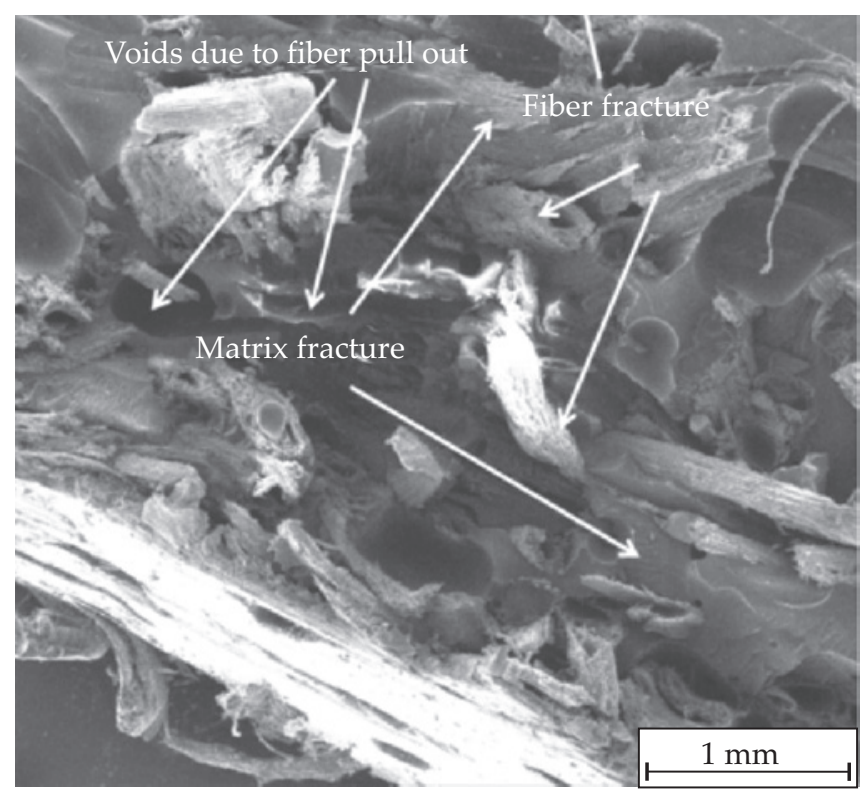

Fig. 11. SEM image of flexural sample of U3035 composite at a magnification $50 \times$ 


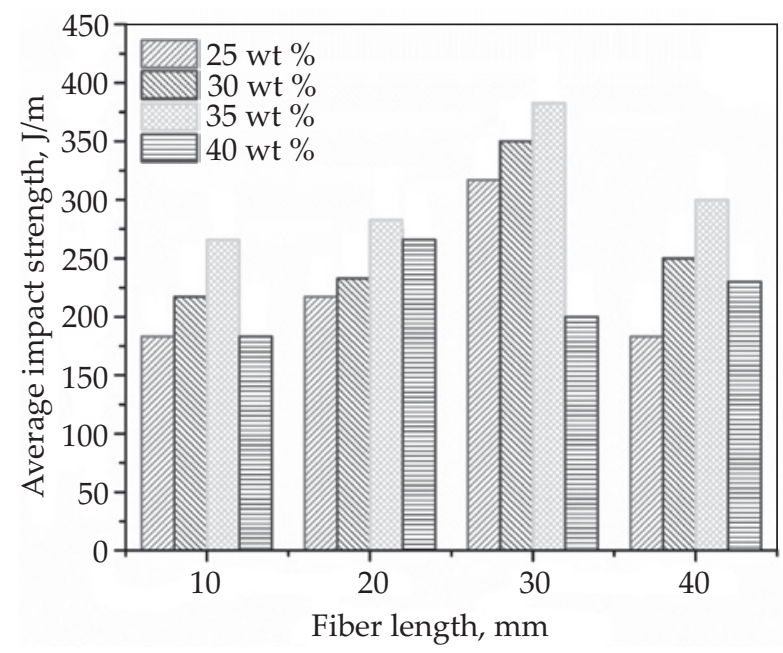

Fig. 12. Impact strength of CIF composites

\section{Flexural studies}

The flexural characteristics were performed for the CIF composite according to ASTM standards. The test results are presented in Table 3 and Fig. 10. It was found that the flexural strength increases with an increase in fiber length and reaches the maximum value $(66.45 \mathrm{MPa})$ at $30 \mathrm{~mm}$ length $\left(l_{c}\right)$. Further increase in the fiber length results in a decrease of the composite flexural strength.

Similarly, the highest flexural strength was obtained for the composite U3035, which contains 35\% of fiber and the loading of fiber above this limit deteriorates the flexural properties. This may be due to the fact that excessive fiber loading may decrease the interfacial bonding between the fiber and the matrix. The same result had been reported by Sreenivasan [8] and Joseph [29]. Figure 11 shows the SEM fractography of the flexural fracture surface of the sample U3035 and it is inferred that the fiber and matrix fractures are predominant in the failure surface which shows that the interfacial bonding is good in the fabricated composite during flexural loading. The observed small voids present in the fractograph are the evidence for the superior bonding strength of the matrix and the fiber in the flexural loading.

\section{Impact studies}

Table 3 and Fig. 12 show the results of the impact studies. They indicate that the impact strength of CIF composite increases with an increase in the fiber length and the loading; the impact strength $(383 \mathrm{~J} / \mathrm{m})$ was observed in U3035. The more the fiber loading and the more the fiber length in the composite, the more the fiber pull out will be and that is due to the entanglement of fiber and thus the impact energy absorbing capacity of the composite drops. Figure 13 shows the SEM fractograph of an impact fracture surface and it is observed that more matrix debris is present with voids due to fiber pull out. These matrix debris and fiber pull out are due to the impact lo-

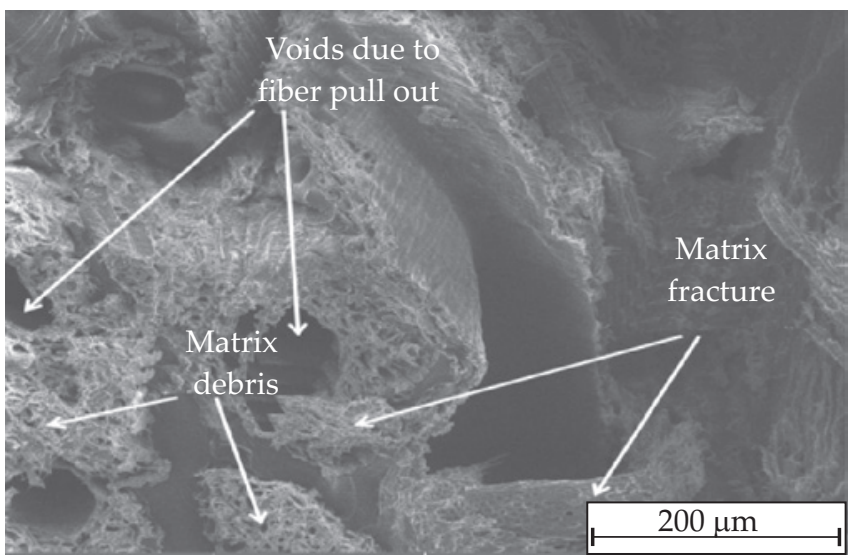

Fig. 13. SEM image of impact test sample of U3035 CIF composite at a magnification $300 \mathrm{x}$

ading. The result obtained in this study matches the result reported by Harish [1].

\section{Compression studies}

Amongst the most essential and estimated properties of materials utilized in different applications, compressive strength plays a vital role. When the material fails to achieve a required compressive strength, the estimation of uniaxial compressive pressure is made. By undergoing the compressive test, the compression strength is found. The difference in compressive strength concerning the fiber length and mixture proportion is shown in Fig. 14 and Table 3. The maximum compressive strength values in the range 34-37 MPa were achieved for the samples with $35 \%$ fiber loading. The minimum values of compressive strength determined for the CI fiber reinforced composites may result from the presence of surface impurities and a weak bonding between the fiber and matrix as well as insufficient fiber fraction. It is concluded that the decrease in compressive strength was achieved when the

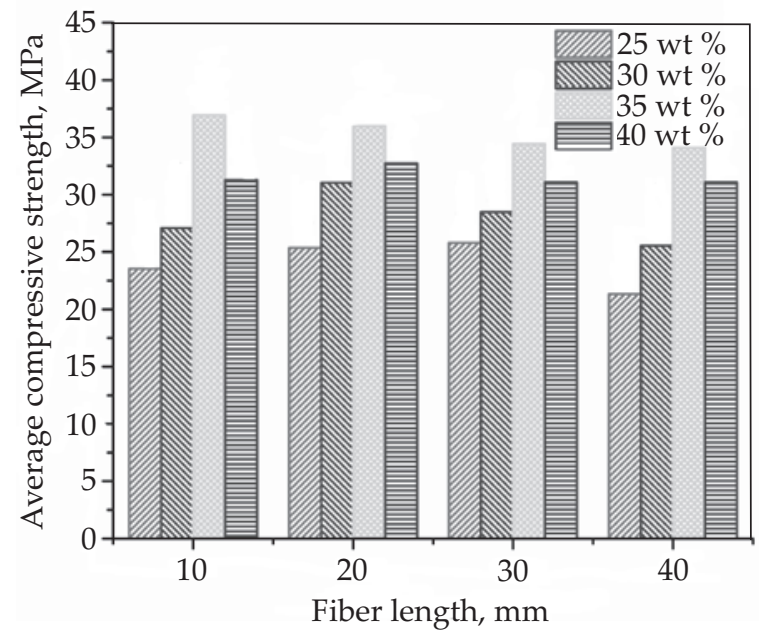

Fig. 14. Compressive strength of CIF composites 
fiber content reached below and above 35\% and below and above the $30 \mathrm{~mm}$ length of the fiber.

\section{CONCLUSIONS}

This research was carried out in two phases. In the first phase, the Coccinia Indica fiber extracted from CI plant stem fiber, was characterized by chemical analysis, FT-IR, TGA, XRD and SEM. Then, in the second phase, the composites with different fiber length and weight percentage were fabricated using a compression molding process and their structural property relationships were characterized by conducting various mechanical tests. The obtained results are presented below:

- The chemical analysis result showed that the CIF contained nearly $70 \%$ of cellulose and the rest includes lignin, ash, wax, and moisture.

- The SEM result of CIF revealed that its single fiber possessed a multi-cellular structure with a diameter of $15 \mu \mathrm{m}$ (approximately).

- The FT-IR studies of CIF revealed that the crystalline index of CI fiber was $30 \%$.

- The TGA analysis of CIF revealed that the major degradation (mass change of $51.0 \%$ ) of CI fiber took place in the third stage (between $204.2^{\circ} \mathrm{C}$ and $376.3^{\circ} \mathrm{C}$ ) with loss of cellulose and some part of lignin.

- The mechanical properties such as tensile, flexural, impact and compressive strength increased with an increase in fiber length and weight percentage. The obtained tensile, flexural, impact and compressive strength of CIF composite (U3035) were $25.5 \mathrm{~N} / \mathrm{mm}^{2}, 66.5 \mathrm{MPa}$, $383 \mathrm{~J} / \mathrm{m}$ and $34.5 \mathrm{MPa}$, respectively.

- The maximum properties were found in the CIF composite U3035 having $30 \mathrm{~mm}$ length and 35\% of fiber loading.

- The SEM fractography showed that the predominant mechanism for mechanical failure was due to fiber pull out, as well as the matrix and fiber fractures.

\section{REFERENCES}

[1] Harish M., Michael D.P., Bensely A. et al.: Materials Characterization 2009, 60 (1), 44. https://doi.org/10.1016/j.matchar.2008.07.001

[2] Bodros E., Baley C.: Materials Letters 2008, 62 (14), 2143. https://doi.org/10.1016/j.matlet.2007.11.034

[3] Boopathi L., Sampath P.S., Mylsamy K.: Composites Part B 2012, 43 (8), 3044. https://doi.org/10.1016/j.compositesb.2012.05.002

[4] Ratna Prasad A.V., Mohana Rao K.: Materials \& Design 2011, 32, 4658. https://doi.org/10.1016/j.matdes.2011.03.015

[5] Holbery J., Houston D.: JOM 2006, 58 (11), 80. https://doi.org/10.1007/s11837-006-0234-2

[6] Sapuan S.M., Maleque M.A.: Materials \& Design 2005, 26,65 . https://doi.org/10.1016/j.matdes.2004.03.015

[7] Husain Barbhuiya A., Ismail K.: International Journal of Polymer Analysis and Characterization 2016, 21 (3), 221.

https://doi.org/10.1080/1023666X.2016.1139282

[8] Sreenivasan V.S., Ravindran D., Manikandan V., Narayanasamy R.: Materials \& Design 2011, 32, 2444. https://doi.org/10.1016/j.matdes.2010.11.042

[9] Matthews F.L., Rawlings R.D.: "Composite Materials: Engineering and Science" $1^{\text {st }}$ Ed., Cambridge, Woodhead Publishing Ltd. 2005, pp. 169-173, 310-311.

[10] Sivasankari B., Anandharaj M., Gunasekaran P.: Journal of Ethnopharmacology 2014, 153 (2), 408. http://dx.doi.org/10.1016/j.jep.2014.02.040

[11] Waisundara V.Y., Watawana M.I., Jayawardena N.: South African Journal of Botany 2015, 98, 1. https://doi.org/10.1016/j.sajb.2015.01.012

[12] Tamilselvan N., Thirumalai T., Elumalai E.K. et al.: Asian Pacific Journal of Tropical Biomedicine 2011, 1 (2), S299. https://doi.org/10.1016/S2221-1691(11)60176-7

[13] Jayaramudu J., Guduri B.R., Rajulu A.V.: International Journal of Polymer Analysis and Characterization 2009, 14 (2), 115. https://doi.org/10.1080/10236660802601415

[14] Fiore V., Scalici T., Valenza A.: Carbohydrate Polymers 2014, 106, 77. http://dx.doi.org/10.1016/j.carbpol.2014.02.016

[15] Jayaramudu J., Maity A., Sadiku E.R. et al.: Carbohydrate Polymers 2011, 86, 1623. https://doi.org/10.1016/j.carbpol.2011.06.071

[16] Segal L., Creely J.J., Martin A.E., Conrad C.M.: Textile Research Journal 1959, 29 (10), 786. https://doi.org/10.1177/004051755902901003

[17] Park S., Baker J.O., Himmel M.E. et al.: Biotechnology for Biofuels 2010, 3, 10. http://dx.doi.org/10.1186/1754-6834-3-10

[18] Indran S., Raj R.E., Sreenivasan V.S.: Carbohydrate Polymers 2014, 110, 423. https://doi.org/10.1016/j.carbpol.2014.04.051

[19] Kiruthika A.V., Veluraja K.: Fibers and Polymers 2009, 10, 193. https://doi.org/10.1007/s12221-009-0193-7

[20] Porras A., Maranon A., Ashcroft I.: Composites B: Engineering 2015, 74, 66. https://doi.org/10.1016/j.compositesb.2014.12.033

[21] Belouadah Z., Ati A., Rokbi M.: Carbohydrate Polymers 2015, 134, 429. http://dx.doi.org/10.1016/j.carbpol.2015.08.024

[22] Reddy K.O., Ashok B., Reddy K.R.N. et al.: International Journal of Polymer Analysis and Characterization 2014, 19, 48. https://doi.org/10.1080/1023666X.2014.854520

[23] Moran J.I., Alvarez V.A, Cyras V.P., Vazquez A.: Cellulose 2008, 15 (1), 149. http://dx.doi.org/10.1007/s10570-007-9145-9 
[24] Kim H.-S., Kim S., Kim H.-J., Yang H.-S.: Thermochimica Acta 2006, 451 (1), 181. https://doi.org/10.1016/j.tca.2006.09.013

[25] French A.D.: Cellulose 2014, 21 (2), 885. https://doi.org/10.1007/s10570-013-0030-4

[26] Yao F., Wu Q., Lei Y. et al.: Polymer Degradation and Stability 2008, 93 (1), 90.

https://doi.org/10.1016/j.polymdegradstab.2007.10.012

[27] Silverio H.A., Neto W.P.F., Dantas N.O., Pasquini D.: Industrial Crops and Products 2013, 44, 427. https://doi.org/10.1016/j.indcrop.2012.10.014

[28] Reddy K.O., Ashok B., Reddy K.R.N. et al.: Polymer Analysis and Characterization 2014, 19 (1), 48. https://doi.org/10.1080/1023666X.2014.854520

[29] Joseph S., Sreekala M.S., Oommen Z. et al.: Composites Science and Technology 2002, 62 (14), 1857. https://doi.org/10.1016/S0266-3538(02)00098-2

Received 7 III 2019

\section{Sieć Badawcza Łukasiewicz - Instytut Inżynierii Materiałów Polimerowych i Barwników, Oddział Elastomerów i Technologii Gumy w Piastowie}

zaprasza do udziału

\section{w 18. Międzynarodowej Konferencji ELASTOMERY'2019 "Stan obecny i trendy rozwoju”}

Warszawa, 26-28 listopada 2019 r.

Przewodniczący Komitetu Naukowego: prof. dr hab. inż. Janusz DATTA

Przewodniczący Komitetu Organizacyjnego: mgr Urszula PAWŁOWSKA

Tematyka konferencji:

- Napełniacze i nanonapełniacze

- Przetwórstwo

- Surowce

- Metody analizy

- Biomateriały

- Modyfikacja elastomerów

- Modelowanie

- Wulkanizacja

- Recykling

Program konferencji obejmuje: referaty plenarne, referaty, komunikaty oraz sesje plakatową.

Język obrad: polski, angielski (z tłumaczeniem symultanicznym).

Terminy:

31 sierpnia 2019 r. - przesłanie formularza zgłoszeniowego

30 czerwca 2019 r. - przesłanie streszczenia artykułu do publikacji w czasopiśmie „Elastomery"

30 września 2019 r. - opłata konferencyjna

20 października 2019 r. - przesłanie pełnego tekstu wystąpienia

Koszt uczestnictwa w konferencji wynosi 1300 PLN (900 PLN studenci i doktoranci) + 23\% VAT.

Opłata obejmuje materiały konferencyjne, wyżywienie oraz udział w uroczystej kolacji.

Miejsce konferencji: Hotel Gromada „Dom Chłopa” w Warszawie

Informacje: mgr Urszula Pawłowska, fax: +48 2272371 96; tel. +48 2272360 20, kom. 534345 150,

e-mail: elastomery2019@impib.pl 